\title{
AKSEPTANSI TEKNOLOGI INFORMASI KOMUNIKASI: PENDEKATAN SOCIAL COGNITIVE THEORY
}

\author{
Irwan Susanto \\ Teknik Informatika, Sekolah Tinggi Teknologi Telematika Telkom; \\ Manajamen Sistem Informasi, Program DIM Universitas Jenderal Soedirman
}

\begin{abstract}
ABSTRAK
Social Cognitive Theory banyak dikenal sebagai teori pembelajaran, teori sikap dan perilaku. Artikel merupakan essay tentang social cognitive theory yang digunakan untuk mengamati perilaku penggunaan (akseptansi) TIK oleh pengguna (user). Beberapa penelitian melakukan pendekatan triadic reciprocal, ada yang menggunakan pendekatan skema akseptansi TIK. Makalah ini mengidentifikasikan bagaimana pendekatan Social Cognitive Theory digunakan untuk menjelaskan hubungan perilaku, sikap, motivasi dan lingkungan dalam pengambilan keputusan penggunaan TIK. Hasil indentifikasi menunjukkan bahwa terdapat dua faktor utama yang berperan dalam memahami hubungan pengaruh tersebut, yaitu self efficacy dan outcome expectation. Pemahaman kedua faktor utama tersebut perlu dibarengi dengan pemahaman perilaku TIK yang diadop.

Kata kunci : social cognitive theory, akseptansi, triadic, efficacy,TIK
\end{abstract}

\section{Pendahuluan}

Salah satu ciri era new economy saat ini adalah pertumbuhan dan perkembangan perekonomian bangsa sangat dipengaruhi oleh kemajuan teknologi informasi dan komunikasi (TIK), sehingga era saat ini sering disebut juga era DOT COM.(Hagemann et al. 2005)(Investopedia n.d.). Banyak peneliti dan praktisi TIK sangat tertarik meneliti tentang penggunaan TIK, performansi pengguna TIK (Abugabah et al. 2009), penerimaan (akseptansi) TIK. Penelitian banyak ditujukan terhadap faktorfaktor yang memotivasi orang menggunakan TIK, manfaat penggunaan TIK (Abugabah et al. 2009), perilaku orang, faktor lingkungan yang mempengaruhi (Wang et al. 2007), keyakinan seseorang akan kemampuannya menggunakan (self efficacy) TIK (Higgins. 2013) (Strong et al. 2006) (Venkatesh.2000) (Compeau et al. 1999) (Alajmi. 2012) (Nurhan et al. 1986).

Banyak penelitian yang membahas tentang fenomena ini dari pendekatan perspektif teori yang berbeda, diantaranya : Theory of Reason Action (Thompson et al. 2013), Theory Acceptance Model (Venkatesh 2000) (Röcker 2009) (Legris et al. 2003) (Kripanont n.d.) (Davis 1989) (Taylor et al. 2013); Theory of Planned Behavior (TPB)
(Road et al. n.d.); Social Cognitive Theory (SCT) (Wang et al. 2007) (Higgins 2013) ( Compeau et al. 1999) (Nurhan et al.1986). Unified theory of Acceptance and Use of Technology (UTAUT), yang merupakan model penggabungan dari model-model sebelumnya (Morris et al. 2003) (Oshlyansky et al. 1904). Dengan menggunakan masing teori-teori tersebut, artikel ini mengamati perilaku (behavior) pengguna (user) TIK dan memandangnya sebagai hasil dari keyakinan (belief) dalam menggunakan teknologi TIK. Davis (1989) menggunakan teori model TRA dan TAM untuk meneliti intention dan use dalam penggunaan aplikasi komputer (word processor). Mathieson (2006) menggunakan teori model TAM dan TPB untuk meneliti intention dalam penggunaan aplikasi komputer dan kalkulator - Taylor (1995 dan 2013) menggunakan model TAM dan TPB untuk meneliti behavior intention dalam penggunaan computing resources center. Morris (2013) menggunakan model UTAUT untuk meneliti individual reaction dan intention to use dalam penggunaan TIK.

Theory of Planned Behavior (TPB) merupakan model teori pengembangan dari model Theory Reasoned Action dimana teori ini mempostulatkan bahwa sikap dapat 
menjelaskan tindakan manusia (attitude could explain human action) (Cara 1997) . TPB telah banyak digunakan menjadi model pada penelitian berbagai bidang perilaku dan untuk memahami perilaku pada barbagai situasi . TPB menjadi model untuk menjelaskan perilaku pengguna (user) terkait hubungan (Abugabah, Sanzogni, and Poropat 2009) dengan keyakinan (belief), sikap (attitude), dan niat (intention) (Abugabah et al. 2009).

Technology Acceptance Model, model yang dikembangkan untuk mempelajari acceptance oleh pengguna / individu terhadap teknologi dengan mempertimbangkan perceived easy of use dan usefulness.(Davis. 1985). TAM dikembangkan pertama kali oleh Fred D. Davis, Jr, tahun 1985. Davis menjelaskan, perceived easy of use dan perceived usefulness berpengaruh terhadap mental perilaku intention to use melalui mediasi mental attitude toward using.

Unified Theory of Acceptance and Use of Technology (UTAUT), merupakan integrasi dari beberpa model sebelumnya yang telah dikembangkan.(Morris et al. 2003) Oleh Venkantesh, Davis dan kawankawan, UTAUT disebut juga sebagai TAM versi ke tiga ( TAM 3).

\section{Tujuan}

Kalau dalam penjelasan di atas sedikit disinggung beberapa teori yang digunakan untuk menjelaskan penggunaan TIK, makalah ini membahas akseptansi penggunaan TIK yang ditinjau dengan pendekatan Social Cognition Theory. Tujuan pembahasan ini adalah untuk menelaah bagaimana pendekatan Social Cognitive Theory digunakan untuk menjelaskan hubungan perilaku, sikap, motivasi, dan lingkungan dalam pengambilan keputusan penggunaan TIK. Dengan teridentifikasikannya kemampuan Social Cognitive Theory dalam menjelaskan akseptansi TIK, diharapkan SCT dapat dikembangkan disesuaikan dengan konteks implementasinya.

\section{Metoda}

Makalah ini merupakan essay yang menyajikan sari hasil penelitian-penelitian tentang akseptansi TIK yang ditinjau dari Social Cognitive Theory. Hasil penelitian diambil dari sumber jurnal yang membahas tentang akseptansi TIK menggunakan pendekatan Social Cognitive Theory.

\section{Review Literatur : Social Cognitive Theory}

Social Cognitive Theory (SCT)

dikembangkan oleh Albert Bandura. Menurut Bandura, kecuali sejumlah refleks dasar, manusia tidak dilengkapi dengan perilaku bawaan lahir, sehingga perilaku (behavior) yang dimilikinya adalah karena hasil pembelajaran (learning). Manusia memiliki bakat alami bawaan lahir yang bisa dikembangkan pula melalui pembelajaran.

Dalam SCT, manusia merupakan human agency, artinya manusia memiliki kapasitas untuk mengarahkan diri sendiri melalui kontrol terhadap proses berpikir, motivasi dan tindakan diri sendiri. Orang harus perlu membedakan pemikiran dari dasar fisiologisnya dan sifat fungsinya. Proses kognitif bukan semata kegiatan otak, tapi juga proses menciptakan pengaruh. Pikiran manusia bersifat generatif, kreatif, proaktif dan self reflektif, bukan hanya reaktif saja. Orang sebagai pemikir melakukan pemikirannya untuk melayani fungsi menentukan / mendefinisikan. Mereka merencanakan pemikiran kegiatan masa mendatang untuk mengantisipasi keadaan yang selalu berubah, mengukur nilai fungsional yang mereka sukai, mengelola dan menerapkan strategi yang telah dipilih, mengevaluasi dasar pertimbangan, resiko, dan antisipasi konsekuensi kebutuhan manakala diperlukan. Masih menurut Bandura, kapabilitas manusia yang merupakan kemampuan kognitif dasar adalah sebagai berikut :

- Symbolising capability, kemampuan manusia untuk mentransformasikan pengalamannya ke dalam simbol-simbol dan kemampuan untuk memprosesnya. Manusia dapat menciptakan ide yang melampaui penginderaannya. 
- Forethought capability, manusia mampu mengatur sebagian besar perilakunya melalui pemikiran antisipatifnya, bukan akibat reaksinya terhadap lingkungan. Manusia mengantisipasi konsekuensi perbuatannya dan menentukan tujuannya.

- Vicarious capability. Manusia memiliki kemampuan mengamati perilaku lingkungan, orang disekelilingnya. Hasil belajarnya bukan dari pengalaman langsung. Belajar menggunakan pengamatan ini keuntungannya memperpendek waktu pembelajaran untuk mendapatkan ketrampilan.

- Self regulatory capability, menusia memiliki kemampuan mengembangkan standar internal yang dipergunakannya untuk mengevaluasi perilakunya sendiri. Kemampuan untuk mengatur diri sendiri inimempengaruhi perilaku selanjutnya.

- Self reflective capability, manusia memiliki kemampuan merefleksikan diri. Manusia dapat menganalisa berbagai pengalamannya dan mengevaluasi apakah proses pemikirannya sudah memadai.

Keagenan manusia (human agency) dikonseptualisasikan sebagai :

- autonomus agency, dimana orang merupakan agen yang sepenuhnya mandiri bagi tindakannya sendiri.
- mechanical agency, di mana manusia bergantung pada faktor lingkungan.

- emergent interactive agency, di mana tindakan manusia merupakan hasil interkasi dirinya dengan lingkungannya (triadic reciprocality).

SCT menjelaskan fungsi-fungsi psykologi melalui interaksi timbal balik tiga faktor yang disebut model Triadic(Bandura 1988). Model Triadic, memiliki tiga komponen pembentuk yaitu, pertama pola perilaku manusia (behavior), kedua bentuk kognitif, affektif dan kejadian-kejadian biologi pada individu (personal), serta ketiga bentuk kejadian-kejadian lingkungan (environment). Ketiga komponen saling berinteraksi timbal balik.(Bandura. 1999). Model triadic reciprocality menjelaskan perilaku manusia (behavior) merupakan hasil interaksi timbal balik antara peristiwa eksternal lingkungan (environment) dan faktor internal (personal).

Bandura menjelaskan melalui Triadic, tiga issue penting yang dapat digunakan untuk meningkatkan fungsi organisasi. Ketiga issue tersebut adalah mengembangkan kompetensi melalui penguasaan modeling, menguatkan keyakinan orang akan kemampuannya sehingga dapat memanfaatkan potensi lebih baik, dan memperkuat motivasi melalui goal system.

\section{Skema Social Cognitive Theory}

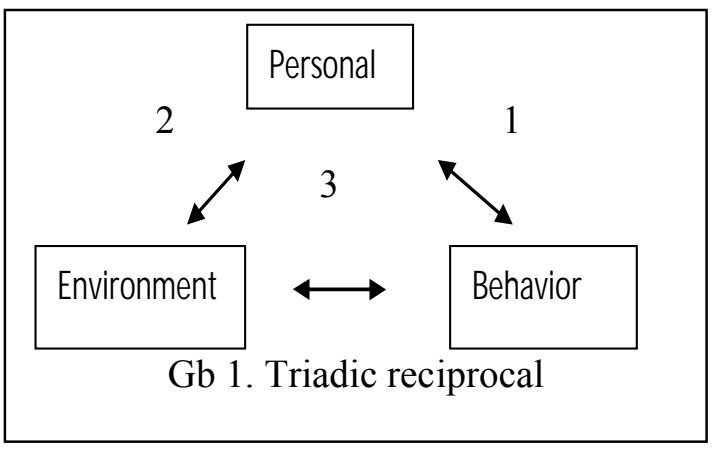

Pada $\mathrm{Gb}$ 1. Triadic reciprocal diatas, thinking, perception, feeling, expectation, Bandura pada Kusluvan (Kusluva 2003) plann, belief, interpretation of event, goal, menjelaskan interaksi timbal balik (1) intention, value) ; personal biological merupakan hubungan interaksi timbal balik properties (misal : sex, ethnicity, personality cognitive process (misal : temperament, genetic predisposition) dengan 
behavior; human attitude (misal : cognitive strategy; metacognitive strategy, providing

Cognitive process;

Personal properties

Interaksi timbal balik (2) merupakan hubungan interaksi timbal balik the external environment (misal: goal, purposive, social feedback, group discussion, social interaction).

Behavior;

human attitude

influences, physical environment, achievement) dengan personality cognitive process; personal properties

Cognnition process; personal properties

Pada interaksi ini behavior dan human attitude belajar dari external environment dengan bantuan cognition process melalui mekanisme belajar seperti modelling, imitation, instruction, social persuasion, anticipation of positive or negative consequence.

Interaksi timbal balik (3) merupakan hubungan interaksi timbal balik behavior; human attitude dengan external environment.

\section{Contoh : social culture}

\section{$\longleftrightarrow \quad$ human activity; people behavior}

Hubungan interaksi timbal balik triadic reciprocal tersebut, selanjutnya dalam implementasi untuk menjelaskan bagaimana orang bisa menerima dan menggunakan TIK untuk membantu menyelesaikan tugastugasnya digambarkan dalam skema seperti pada Gambar 2.

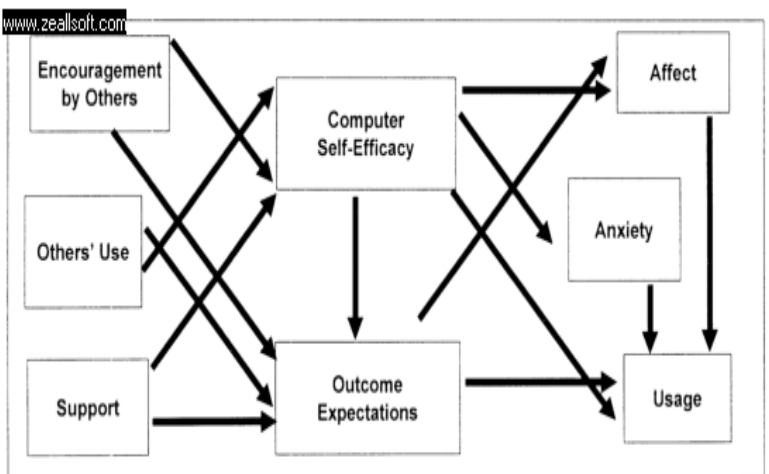

Gambar 2. Skema model akseptansi TIK

Encourage by others

Encourage by others, dipahami sebagai kepada siapa seseorang berharap mendapatkan petunjuk tentang ekspektasi perilaku. Orang tersebut dapat mempengaruhi self efficacy maupun outcome expectation. Orang ini biasanya berada dalam lingkungan organisasinya. Encourage of use merepresentasikan 'verbal persuasion', salah satu dari empat sumber informasi efficacy. Seseorang mengandalkan opini oleh orang lain untuk memperkuat self efficacy. Jika orang memberikan penguatan, sehingga penguatan yang dirasakan menyebabkan kredibilitas yang tinggi, maka penguatan self efficacy akan terjadi. Jika orang sumber penguat memberikan penguatan dalam penggunaan TIK, maka orang yang diberi penguatan akan terpengaruh, akan menguatkan self efficacy dan outcome expectation-nya. 
Other's use

Other's use, sebagai sumber informasi efficacy dan output expectation bagi orang lain. Perilaku seseorang dalam menggunakan teknologi menjadi sumber informasi dalam pembentukan self efficacy dan outcome expectation(Higgins 2013) orang lain. Orang belajar secara observasi menggunakan model merupakan tahapan awal pembelajaran dan menjadi sarana pembelajaran yang efektif.(Higgins 2013)(Bandura 1988). Pemodelan perilaku mempengaruhi perilaku individu pada self efficacy dan juga output expectation.(Higgins 2013)

\section{Support}

Support diberikan organisasi dalam hal penggunaan TIK bisa pula mempengaruhi self efficacy seseorang. Supervisor memiliki peran penting dalam memotivasi dan mengarahkan karyawan dalam penggunaan TIK. Peran ini membutuhkan kemampuan interpesonal skill supervisor.(Bandura 1988)

Computer self efficacy

Computer self efficacy adalah persepsi penilaian seseorang tentang kemampuan dirinya menggunakan komputer.(Nurhan et al. 1986). SCT menunjukkan peran penting persepsi Self efficacy dalam memotivasi seseorang melalui outcome expectation. Orang yang memiliki self efficacy tinggi akan melakukan persiapan dengan kerja keras, serius, dan kreatif untuk mendapatkan kesuksesan (outcome expectation)(Bandura. 1988). Keyakinan (belief) seseorang berdampak (affect) pada emosi seseorang.Orang yang meyakini mereka dapat mengatasi pekerjaan yang sulit sekalipun, tidak akan mudah menyerah. Sebaliknya orang yang keyakinan dirinya rendah, akan mengalami mudah stress, khawatir. Orang yang memiliki keyakinan diri dapat menentukan pilihannya.

Outcome Expectation

Outcome Expectation, dipahami sebagai hasil yang diharapkan dalam penggunaan TIK.(Compeau et al. 1999). Outcome expectation mewakili konskuens yang diinginkan individu dalam menggunakan TIK. Outcome expectation ada dua dimensi yaitu pertama performance-related outcome expectation, yaitu outcome expectation yang berkaitan dengan pengembangan kinerja dengan menggunakan TIK. Kedua personal outcome expectation yaitu outcome expectation yang terkait dengan harapan untuk mendapatkan perubahan citra atau status dalam pekerjaan.

\section{Affect, Anxiety}

Affect merepresantasikan affektif respon seseorang dalam penggunaan TIK. Affect menggambarkan respon positif - menikmati, gembira - seseorang pada saat menggunakan TIK. (Compeau et al. 1999). Anxiety juga merepresantasikan affektif respon seseorang dalam penggunaan TIK. Anxiety menggambarkan respon negatif - gelisah, prihatin - seseorang pada saat menggunakan TIK. (Compeau et al. 1999). Kecenderungan kesukaan seseorang berpengaruh terhadap tindakan yang dilakukan orang tersebut. Konsumen memilih barang karena salah satunya faktor affektif, menyukai atau tertarik barang tersebut. Namun dalam hal hubungan kesukaan seseorang terhadap penggunaan komputer dengan praktek menggunakan komputer dalam pekerjaan, hubungannya lemah.(Higgins 2013). Perasaan kegelisahan (anxiety), kekhawatiran dalam penggunaan TIK berpengaruh negatif dalam perilaku menggunakan TIK. Tidak mengherankan jika orang yang memiliki perasaan kekhawatiran cenderung menghindari penggunaan TIK.

\section{Hubungan Variabel secara empirik Hubungan Antar Variabel Menggunakan Skema Triadic Reciprocal \\ Pengaruh Personality}

Menunjuk pada Gambar 1 triadic reciprocal, Shu-Ling dan kawan-kawan melukiskan beberapa karakteristik pribadi, komponen motivasi ke dalam komponen personal yaitu self-efficacy pada level individu dan level kelompok, task value, dan anxiety. 
Tiga komponen motivasi diyakini memberikan pengaruh yang signifikan terhadap prestasi akademik: (1) pengaruh self efficacy ('? Dapatkah saya melakukan tugas'); (2) pengaruh task value ('Mengapa saya melakukan tugas ini ?; dan (3) pengaruh anxiety (' Bagaimana saya merasakan tugas ini' ) .

Self-efficacy, persepsi orang tentang kemampuan mereka untuk melaksanakan tindakan yang diperlukan untuk mencapai hasil tertentu memiliki pengaruh yang kuat pada pilihan aktivitas, usaha dikeluarkan, kesediaan untuk bertahan dan penyelesaian tugas. Penelitian juga menunjukkan bahwa self-efficacy memiliki efek yang kuat pada kinerja pembelajaran berbasis web. Hasil penelitian menunjukkan bahwa siswa dengan efficacy yang tinggi akan menggunakan skil kognitifnya lebih tinggi.

Komponen value, khususnya task value, berhubungan dengan perilaku prestasi. Meskipun ada beberapa hasil penelitian yang berpendapat bahwa nilai tugas adalah prediktor / alasan yang lebih baik untuk perilaku memilih seperti memilih pendaftaran dalam kursus dan niat untuk mengambil kursus di masa depan daripada alasan prestasi yang sebenarnya.

Motivasi Grup memiliki efek yang signifikan terhadap kinerja kelompok. Keyakinan anggota tim atau kemampuan tim untuk mencapai tujuan pembelajaran, telah terbukti berkorelasi positif dengan kinerja kelompok dalam sejumlah penelitian pada bidang-bidang seperti sekolah, organisasi dan olahraga. 'Keberhasilan kolektif' dalam tim berkaitan dengan kemampuan kelompok secara keseluruhan. Penelitian menunjukkan bahwa 'keberhasilan kolektif' memiliki hubungan signifikan dengan variabelvariabel fungsi kelompok, seperti 'tingkat usaha', 'ketekunan' dan 'prestasi'.

\section{Pengaruh Behavior}

Hal-hal yang banyak dibahas dalam dampakdampak perilaku (behavioral influence) diantaranya learning strategy, feedback dan group discussion. Hasil penelitian yang membahas tentang issue kognitif seperti latihan, elaborasi, belajar kelompok menunjukkan berpengaruh penting pada proses pembelajaran mandiri, prestasi akademik, pembelajaran dan kinerja. Sebagai contoh, penelitian tentang penggunaan strategi dan pengolahan informasi menunjukkan bahwa penggunaan elaborasi dan strategi organisasi dapat membantu siswa lebih baik dalam mengembangkan pemahaman siswa dibandingkan dengan strategi latihan sederhana.

Strategi metakognitif sangat penting dalam penyelidikan berbasis konstruksi pengetahuan. Strategi metakognitif terdiri dari tiga jenis umum strategi: perencanaan, monitoring, dan mengatur. Penelitian menunjukkan bahwa penggunaan strategi metakognitif memiliki efek positif pada prestasi akademik siswa. Selain itu, penelitian tentang pembelajaran kolaboratif yang didukung komputer menunjukkan bahwa strategi metakognitif penting untuk konstruksi pengetahuan berbasis inquiry. Sebuah studi terbaru yang dilakukan di lingkungan berbasis web juga menunjukkan bahwa siswa yang diminta untuk memantau perkembangan mereka menunjukkan prestasi yang lebih baik daripada mereka yang tidak melakukaan pemantauan. Selain penggunaan strategi kognitif atau metakognitif penggunaan metode umpan balik juga memberikan pengaruh pada hasil pembelajaran. Beberapa penelitian menunjukan hasil bahwa dalam prosese pembelajaran akan lebih efektif bila peserta didik memberikan umpan balik. Kritikan akan menjadi masukan dalam perbaikan kualitas pembelajaran. Terutama kritikan dari siswa yang kritis akan memberikan umpan balik berkualitas tinggi. Dari perspektif kognitif sosial, siswa yang lebih aktif terlibat dalam pembelajaran mereka, seperti memberikan umpan balik berkualitas tinggi, lebih mungkin untuk menunjukkan perilaku belajar yang lebih baik dan prestasi akademik.

Issue lain dalam behavior influence adalah group discussion. Issue group discussion merupakan issue perilaku individu karena perilaku kelompok. Sifat pembelajaran yang 
dianut dalam kelompok berpengaruh dalam perilaku individu. Pembelajaran kolaboratif akan meningkatkan hasil belajar. Namun begitu hasil peneliti lain menunjukkan ada beberapa potensi negatif dari pembelajaran kolaboratif seperti menunggang gratis, kemalasan sosial dan pengabaian tanggung jawab, terutama ketika pemantauan guru tidak bisa langsung.

Beberapa penelitian tentang metode pembelajaran menunjukkan bahwa pembelajaran kolaboratif berbasis web dapat meningkatkan hasil belajar lebih baik daripada pembelajaran kolaboratif tradisional. Penelitian menunjukkan bahwa anggota kelompok yang sangat kognitif terlibat dalam diskusi kelompok berbasis web cenderung memiliki prestasi akademik yang lebih baik. Selain itu, penelitian juga menunjukkan bahwa kualitas komunikasi selama interaksi kelompok berhubungan positif dengan kinerja kelompok. Dapat digaris bawahi bahwa perilaku berbasis kelompok seperti diskusi atau interaksi kelompok memainkan peran yang sangat penting dalam pembelajaran kolaboratif berbasis web.

\section{Pengaruh Environment}

Pengaruh lingkungan seperti feedback (contoh peer assesment dari teman, teacher assesment dari guru) dan pemodelan digunakan untuk upaya meningkatkan kinerja. Feedback terbukti sebagai mekanisme yang efektif pada social learning, meningkatkan prestasi akademik dan meningkatkan motivasi. Penelitian menunjukkan bahwa menerima umpan balik berkorelasi dengan belajar yang efektif. Secara khusus, menerima umpan balik secara langsung ataupun tidak langsung dapat mencegah beberapa kesalahan dan memberikan petunjuk untuk membuat kemajuan. Umpan balik yang spesifik jauh lebih akan memberikan dampak yang lebih baik daripada umpan balik umum. Penelitian menunjukkan bahwa penilaian sejawat merupakan strategi penilaian yang baik. Dalam proses pembelajaran penilaian sejawat memungkinkan siswa untuk menjadi lebih terlibat dalam kegiatan kelas.

Disampaing feedback, pemodelan dapat mempengaruhi hasil belajar seseorang. Sebagai contoh seseorang mampu belajar keterampilan kompleks dengan mengamati pertunjukan model. Mengamati rekan-rekan yang sama menyelesaikan tugas dengan sukses dapat menyampaikan rasa self-efficacy sehingga dapat meningkatkan kinerja. Sebuah studi pelatihan keterampilan komputer menunjukkan bahwa pemodelan perilaku berdampak pada self efficacy dan kinerja komputer. Ketika seseorang melihat orang lain (model) mampu mengoperasikan komputer, tanpa disadari akan melakukan pembandingan dengan menganalogikan kemampuan dirinya sendiri, sehingga akan meningkatkan motivasi dan keyakinan diri sendiri akan kemampuannya (self efficacy) yang pada akhirnya akan meningkatkan kemampuan skillnya dalam menggunakan komputer.

\section{Hubungan antar variabel menggunakan skema model akseptansi TIK}

Telaah ini meninjau pendekatan perspektif Teori Kognitif Sosial menggunakan skema model akseptansi TIK (Gb. 2) pada perilaku komputasi. Akseptansi TIK merupakan bentuk perilaku penerimaan seseorang terhadap penawaran TIK. Akseptansi TIK diwujudkan dalam bentuk usage TIK. Dorongan seseorang bisa menerima TIK disebabkan karena keyakinan akan kemampuannya (self efficacy), harapan jika menggunakan TIK (outcome expectance), respon positif ketika sudah mencoba menggunakan (affect) dan terkendala respon negatif berupa kekhawatiran (anxiety). Hasil penelitian menunjukkan self-efficacy dapat memainkan peran penting dalam membentuk perasaan dan perilaku individu. Seseorang yang memiliki computer self-efficacy yang tinggi, akan lebih banyak menggunakan komputer dibandingkan orang yang memiliki computer self-efficacy rendah, karena bisa menikmati (affect) dan tidak banyak merasakan kecemasan (anxiety). Disamping itu yang 
bersangkutan akan cenderung bekerja keras mempersiapkan diri untuk mendapatkan prestasi (outcome expectation). Selanjutnya, outcome expectation, khususnya yang berkaitan dengan prestasi kerja, ditemukan memiliki pengaruh terhadap affect dan computer use. Affect dan anxiety juga berpengaruh terhadap computer use, namun dalam arah yang berbeda. Affect mempengaruhi positif sebalilknya kecemasan memberikan pengaruh negatif pada penggunaan komputer.

Skema model Gb. 2, menggambarkan bagaimana pengaruh faktor lingkungan (encourage by others, others' use dan support) mendorong munculnya self-efficacy dan outcome expectation dalam proses environmental information. Beberapa penelitian menunjukkan pengaruh encourage of use pada computing behavior. Terdapat penelitian yang mengemukakan hubungan langsung encourage of use dengan usage. Sebagian penelitian (Higgins. 2013) menunjukkan encourage of use mempengaruhi perilaku secara tidak langsung, melalui pengaruhnya terhadap selfefficacy dan outcome expectation.

Ada sedikit ironi temuan, yaitu pengaruh negatif dari self-efficacy dan outcome expectation. Dari perspektif teoritis, tampaknya logis untuk menduga bahwa dukungan organisasi (support) yang lebih tinggi akan menghasilkan penilaian selfefficacy pada level individu yang lebih tinggi, karena mereka akan memiliki lebih banyak sumber daya untuk menjadi mereka lebih mahir. Selain itu, support organisasi diyakini menjadi indikator norma organisasi mengenai use, dan berpengaruh positif terhadap outcome expectation dan self

\section{DAFTAR PUSTAKA}

Abugabah, Ahed, Louis Sanzogni, and Arthur Poropat. 2009. "The Impact of Information Systems on User Performance : A Critical Review and Theoretical Model." In ed. Cemal Ardil. Nathan, Brisbane, QLD 4111, Australia: WASET, 13. http://www98.griffith.edu.au/dspace/handle/10072/31849.

Alajmi, Bibi M. 2012. "The Intention to Share: Psychological Investigation of Knowledge Sharing Behaviour in Online Communities." Journal of Information \& Knowledge Management 11(3): 1250012-22. 10.1142/S0219649212500220.

Bandura, Albert. 1988. “Organisational Application of Social Cognitive Theory.” Australian 
Journal of Management 13(2): 28.

1999. "Social Cognitive Theory : An Agency Perspective." Asian Journal of Scocial Psychology 2: 21-41.

Cara, Pauls; Jill Levine; 1997. "Theory of Reasoned Action / Theory of Planned Behavior."

Compeau, Deborah, Christopher A Higgins, and Sid Huff. 1999. "Social Cognitive Theory And Individual Reactions To Computing Technology: A Longitudinal Study." MIS Quarterly 23(2): 145-58. http://www.jstor.org/stable/249749 .

Compeau, Deborah R., and Christopher a. Higgins. 1995. "Application of Social Cognitive Theory to Training for Computer Skills." Information Systems Research 6(2): 118-43. http://pubsonline.informs.org/doi/abs/10.1287/isre.6.2.118.

Davis, Fred D. 1989. "Perceived Usefulness, Perceived Ease of Use, and User Acceptance of Information Technology.” MIS Quarterly (September).

Hagemann, Harald, Bruno Amable, Martin Heidenreich, and European Studies. 2005. The New Economy in Transatlantic Perspective. 1st ed. ed. Kurt Hubner. New york: Routledge, Taylor \& Francis Group.

Higgins, Christopher A. 2013. "Computer Sefl-Efficacy : Development of Measure and Initial Test." 19(2): 189-211.

Investopedia. "Five Chart Patterns You Need to Know." http://www.investopedia.com/terms/n/neweconomy.asp.

Jr, Fred D Davis. 1985. “A Technology Acceptance Model For Empiricall Testing New EndUser Information Systems : Theory and Result."

Kreitner, Robert, and Angelo Kinicki. 2003. Organization Behavior (terjemahan). 1st ed. Mc Graw Hill Companies Inc.

Kripanont, Napaporn. "Using a Technology Acceptance Model to Investigate Academic Acceptance of the Internet." 1(2): 13-28.

Kusluva, Salih, ed. 2003. Managing Employee Attitude and Behaviors in the Tourism and Hospitality Industry. New York: Nova Science Publisher.

https://books.google.co.id/books?id=eQp1t_1HgzwC\&pg=PA31\&dq=triadic+reciprocal $\& \mathrm{hl}=\mathrm{jv} \& \mathrm{sa}=\mathrm{X} \& \mathrm{ei}=7 \mathrm{CHrVNKPIMaTuASUuoDACA} \&$ redir_esc $=\mathrm{y} \# \mathrm{v}=$ onepage $\& \mathrm{q}=$ triadi $\mathrm{c}$ reciprocal $\& \mathrm{f}=$ false.

Legris, Paul, John Ingham, and Pierre Collerette. 2003. "Why Do People Use Information Technology? A Critical Review of the Technology Acceptance Model.” Information \& Management 40(3): 191-204.

http://linkinghub.elsevier.com/retrieve/pii/S0378720601001434.

Mathisen, Gro Ellen, Torbjørn Torsheim, and Ståle Einarsen. 2006. "The Team-Level Model of Climate for Innovation: A Two-Level Confirmatory Factor Analysis." Journal of Occupational and Organizational Psychology 79(1): 23-35. http://doi.wiley.com/10.1348/096317905X52869 (February 20, 2015).

Morris, Michael G et al. 2003. "User Acceptance Of Information Technology : Toward a Unified View .” MIS Quarterly 27(3): 425-78. http://nwresearch.wikispaces.com/file/view/Venkatesh+User+Acceptance+of+Informatio n+Technology+2003.pdf. 
Nurhan Özturk, Esra Bozkurt, Tezcan Kartal, Ramazan Demir, Gülay Ekici. 1986.

"Evaluation Of Prospective Science Teachers ' Computer." Western Anatolia journal of Educational Science: 181-88.

Oshlyansky, Lidia, Singleton Park, Paul Cairns, and Harold Thimbleby. 1904. "Validating the Unified Theory of Acceptance and Use of Technology ( UTAUT ) Tool CrossCulturally."

Road, Glades, and Boca Raton. "User Acceptance Of E-Commerce Technology : A MetaAnalytic Comparison Of Competing Models ." : 179-90.

Röcker, Carsten. 2009. "Perceived Usefulness and Perceived Ease-of-Use of Ambient Intelligence Applications in Office Environments 2 Technology Adoption.” : 1052-61.

Strong, Diane M, Mark T Dishaw, and D Brent Bandy. 2006. "Extending Task Technology Fit with Computer Self-Efficacy.” SIGMIS Database 37(2-3): 96-107. http://doi.acm.org/10.1145/1161345.1161358.

Taylor, Shirley, and Peter Todd. 2013. "Assessing IT Usage : The Role of Prior Experience." 19(4): 561-70.

Thompson, Ronald L et al. 2013. "Personal Computing: Toward a Conceptual Model of Utilization1." MIS Quarterly 15(1): 125-43. http://www.jstor.org/discover/10.2307/249443?uid=3738224\&uid=2129\&uid=2\&uid=70 \&uid $=4 \& \operatorname{sid}=2110440580461$.

Venkatesh, Viswanath. 2000. "Determinants of Perceived Ease of Use : Integrating Control, Intrinsic Motivation , and Emotion into the Technology Acceptance Model." Information System Research 11(4): 342-65. http://dl.acm.org/citation.cfm?id=768947.

Wang, Shu-Ling, and Sunny S. J. Lin. 2007. "The Application of Social Cognitive Theory to Web-Based Learning through NetPorts." British Journal of Educational Technology 38(4): 600-612. http://doi.wiley.com/10.1111/j.1467-8535.2006.00645.x (October 10, 2014). 